\title{
A novel role for Livin in the response to ultraviolet $B$ radiation and pterygium development
}

\author{
SHUANG-QING WU, QI-BIN XU, WEN-YAN SHENG, LIN-YA SU and LI-WEI ZHU \\ Department of Ophthalmology, Zhejiang Medicine and Western Medicine Integrated Hospital \\ (Hangzhou Red-Cross Hospital), Hangzhou, Zhejiang 310003, P.R. China
}

Received July 29, 2019; Accepted December 4, 2019

DOI: $10.3892 /$ ijmm.2020.4481

\begin{abstract}
A pterygium is an inflammatory, invasive and proliferative lesion on the ocular surface, which can decrease visual acuity, damage the ocular surface and affect the appearance of the eye. However, the underlying molecular mechanisms of the pathogenesis remain unclear. In the present study, the role of apoptosis-associated protein Livin in the occurrence and development of pterygium was investigated. Primary samples from quiescent or advanced clinical stages of pterygium and normal human conjunctival tissues were used to assess mRNA and protein expression levels of Livin using reverse transcription-quantitative PCR and immunohistochemistry, respectively. Livin was knocked down in pterygium epithelial cells (PECs) using small interfering RNA (siRNA), to investigate the role of Livin in PEC viability, migration, invasion ability and apoptosis. The cell viability, invasion ability and apoptosis of PECs following ultraviolet B (UVB) radiation alone or in combination with Livin silencing were also analyzed. Expression levels of Livin increased in the pterygium tissues compared with those in the normal conjunctiva at both the mRNA and protein levels. Livin expression levels in advanced pterygium were significantly higher compared with those in quiescent pterygium samples. Knockdown of Livin expression levels significantly reduced cell migration, invasion ability and cell viability, and induced apoptosis of PECs. Inhibition of Livin expression in PECs increased the expression levels of caspase-7, caspase-3 and E-cadherin, whereas expression levels of Snail were downregulated. Cell viability and invasion ability in PECs was enhanced following UVB radiation and Livin expression upregulated. UVB irradiation induced cell invasion ability of PECs and this was attenuated by Livin-silencing. Transfection with Livin siRNA also partially
\end{abstract}

Correspondence to: Dr Li-Wei Zhu, Department of Ophthalmology, Zhejiang Medicine and Western Medicine Integrated Hospital (Hangzhou Red-Cross Hospital), 208 Huancheng Road East, Hangzhou, Zhejiang 310003, P.R. China

E-mail: zlwgsy@163.com

Key words: pterygium, Livin, ultraviolet $\mathrm{B}$ radiation, pterygium epithelial cells, apoptosis recovered the apoptosis rate of PECs, which was reduced by UVB irradiation. In conclusion, Livin was upregulated in pterygium, and UVB radiation functions in the development of pterygium by inducing Livin expression.

\section{Introduction}

Pterygium is a common disease of the ocular surface, characterized by invasion of triangular inflammatory fibrovascular lesions into the cornea, which can cause inflammation, irregular corneal astigmatism and stromal opacity (1). Currently, the underlying mechanisms of pterygium have not been well elucidated and surgical excision is the standard treatment; however, pterygium recurrence is common following surgery (2). In order to devise strategies for the non-surgical treatment of pterygium or the prevention of recurrence after resection, it is important to understand the underlying molecular mechanisms of the pathogenesis of pterygium.

Pterygium is more common in tropical and subtropical zones, and epidemiological evidence indicates that the pathogenesis of pterygium is strongly associated with high exposure to ultraviolet (UV) radiation (3). UV radiation induces expression of several proinflammatory cytokines, including transforming growth factor- $\beta$, interleukin (IL)-1, IL-6, and IL-8, and growth factors, including fibroblast growth factor and vascular endothelial growth factor, which promote the progression of pterygium (3-6); however, the exact mechanism by which UV leads to the onset of pterygium remains unclear.

Pterygium exhibits tumor-like features, including propensity to invade normal tissue, recurrence after excision and coexistence with premalignant lesions $(4,7,8)$. Previous studies have demonstrated that pterygium epithelial cells (PECs) are highly proliferative, have features of epithelial-mesenchymal transition (EMT) and overexpress anti-apoptotic proteins (9-13). Livin is a member of the inhibitors of apoptosis protein (IAP) family (14), which function in tumor initiation, progression and resistance to chemotherapy (15). Livin has been reported to serve a prominent and specific role in certain malignancies and is associated with diverse cellular behaviors, including proliferation, invasiveness and motility (14). However, the role of Livin in ocular surface diseases has not been previously reported, and to the best of our knowledge, there is no research investigating the expression and molecular mechanisms of Livin in the development of pterygium. 
In the present study, the expression levels and distribution of Livin in pterygium was investigated and the association between UVB radiation and Livin expression levels was explored. Knockdown of Livin expression was used to investigate the function of Livin in the cellular behavior of pterygium epithelium and the potential underlying molecular mechanisms.

\section{Materials and methods}

Patients and samples. The present study was in compliance with The Declaration of Helsinki and was approved by the Institutional Review Board of Hangzhou Red-Cross Hospital (Hangzhou, China). All patients provided written informed consent. A total of 19 male and 16 female patients with primary pterygium (age range, 52-79 years; mean age, 60.3 \pm 7.7 years), treated at Hangzhou Red-Cross Hospital between November 2018 and March 2019, were included in the present study. Exclusion criteria included a history of any other ocular surface disorders, previous ocular surgery, ocular trauma, systemic autoimmune disease or inflammation and use of any topical steroids or non-steroidal anti-inflammatory drugs. Normal conjunctival tissue segments from the nasal bulbar conjunctiva near the limbus were obtained from 10 individuals ( 6 men and 4 women; age range, 44-69 years; mean age, $56.6 \pm 8.9$ years) during retinal surgeries as control group samples.

Pterygia were classified into two stages based on the invasion of the pterygium, the number of new blood vessels and the transparency of the tissue (16). A total of 17 samples were classified as of quiescent stage, characterized by mild invasion, hyperemia and moderate transparency, whereas 18 samples were classified as of advanced stage, characterized by aggression, dense neovascularization and opacity of the pterygium. Excised tissues were divided laterally into two symmetrical pieces of identical size. One piece (for measurement of Livin mRNA) was frozen and stored at $-80^{\circ} \mathrm{C}$ and the other piece was fixed in $10 \%$ buffered formaldehyde solution and embedded in paraffin before subsequent experiments ( $<3$ months).

Reverse transcription-quantitative (RT-q)PCR. Normal conjunctival tissue and pterygium were cut and ground, then $1 \mathrm{ml} \mathrm{TRIzol}{ }^{\circledR}$ (EZBioscience) was used to extract total cellular RNA according to the manufacturer's protocol. Subsequently, RNA purity and concentration were measured using a Nanodrop 2000 (Thermo Fisher Scientific, Inc.), then RNA was reverse transcribed to cDNA using a Revert Aid First Strand cDNA Synthesis kit (Thermo Fisher Scientific, Inc.). qPCR was performed using SsoAdvance Universal SYBR-Green Supermix (Bio-Rad Laboratories, Inc.). PCR was performed at $95^{\circ} \mathrm{C}$ for $3 \mathrm{~min}$, then for 40 cycles at $95^{\circ} \mathrm{C}$ for $10 \mathrm{sec}, 60^{\circ} \mathrm{C}$ for $30 \mathrm{sec}$ and $72^{\circ} \mathrm{C}$ for $30 \mathrm{sec}$. The primer sequences of the target genes were as follows: Livin forward, 5'-ACAGAGGAGGAA GAGGAGGAGG-3' and reverse 5'-GCAGTCAGCGGCCAGT CAT-3'; and $\beta$-actin forward, 5'-GAACCCTAAGGCTAACAG AGAAA-3' and reverse, 5'-CCACTAGCATAAAGGGAGAG AAC-3'. $\beta$-actin was used as an internal control. The experimental results were automatically calculated using a CFX96Touch ${ }^{\mathrm{TM}}$ Real-Time PCR Detection system (Bio-Rad Laboratories, Inc.). The relative expression of Livin gene was expressed as a fold-increase of $\beta$-actin calculated using the $2^{-\Delta \Delta \mathrm{Cq}}$ method (17).
Immunohistochemistry analysis. The tissues were fixed in a $10 \%$ formalin solution and embedded in paraffin. Samples were cut into $4-\mu \mathrm{m}$ sections, mounted on glass and dried overnight at $37^{\circ} \mathrm{C}$. All sections were then deparaffinized in xylene, rehydrated with alcohol $(100 \%$ ethanol for $2 \times 3 \mathrm{~min}$; $95 \%$ ethanol for $3 \mathrm{~min} ; 70 \%$ ethanol for $3 \mathrm{~min}$; $50 \%$ ethanol for $3 \mathrm{~min}$ ) and washed in PBS. Sections were then inactivated using $3 \% \mathrm{H}_{2} \mathrm{O}_{2}$ for $10 \mathrm{~min}$. Sections were heated to $100^{\circ} \mathrm{C}$ in EDTA ( $\mathrm{pH}$ 9.0) for $10 \mathrm{~min}$ and then naturally cooled and soaked in PBS three times for $3 \mathrm{~min}$ each. The sections were blocked in a $37^{\circ} \mathrm{C}$ oven for 45 min using $5 \%$ BSA (Sigma-Aldrich; Merck KGaA). The immunohistochemistry experiment was conducted using the streptavidin-biotinperoxidase method (18). Anti-Livin primary antibody (cat no. ab93750; 1:50; Abcam) was applied to the sections and incubated overnight at $4^{\circ} \mathrm{C}$. 3,3'-Diaminobenzidine was used as a chromogen, followed by rinsing with water for $5 \mathrm{~min}$ and counterstaining with hematoxylin for $2 \mathrm{~min}$ at room temperature.

The numbers of epithelial cells and Livin-positive cells of the pterygium or normal conjunctiva were counted in three independent fields using a high-power field under a light microscope (magnification, $\mathrm{x} 40$ ). Cells positively stained for the anti-Livin antibody were scored according to the percentage extent of staining and the measurements were averaged. Scores were as follows: 0 , no positive staining;,$+ 1-10 \%$;,$++ 11-50 \%$; and,$+++>50 \%$ positive cells. Scores of,+++ and +++ were considered to represent positive immunostaining, whereas a score of 0 indicated negative immunostaining. All evaluations of the staining were conducted by an observer blinded to the origins of the tissue samples.

Western blot analysis. Total protein was extracted from patient tissues using RIPA lysis buffer (Beyotime Institute of Biotechnology) and $20 \mu \mathrm{g}$ protein/lane was loaded onto a $12 \%$ gel, resolved using SDS-PAGE and subsequently transferred to PVDF membranes (EMD Millipore). PVDF membranes were immersed in a blocking solution containing $5 \%$ skimmed milk powder in PBS or 5\% BSA and blocked at room temperature for $2 \mathrm{~h}$. Subsequently, the membranes were incubated with primary antibodies at $4^{\circ} \mathrm{C}$ overnight, followed by secondary antibodies at room temperature for $2 \mathrm{~h}$. The proteins were visualized using a Clarity ${ }^{\mathrm{TM}}$ Western ECL Substrate (Bio-Rad Laboratories, Inc.) and detected using a chemiluminescence detection system (ChemiDoc MP; Bio-Rad Laboratories, Inc.) and the bands were analyzed using ImageJ software (v1.46; National Institutes of Health). Anti-GAPDH antibodies were used as an internal control (cat. no. cst5174; 1:1,000; Cell Signaling Technology, Inc.). The primary antibodies included anti-Livin (cat. no. NB100-56548; 1:500-1:2,000; Novus Biologicals, Ltd.), anti-caspase-7 (cat. no. ab32522, 1:1,000; Abcam), anti-caspase-3 (cat. no. cst9662; 1:1,000; Cell Signaling Technology, Inc.), anti-E-cadherin (cat. no. 610405; 1:1,000; BD Biosciences), anti-Snail (cat. no. cst3879; 1:1,000; Cell Signaling Technology, Inc.) and anti-poly ADP-ribose polymerase (cat. no. ab74290; PARP; 1:4,000, Abcam). The secondary antibodies included goat anti-rabbitIgG (cat. no. BL003A; 1:5,000; Biosharp Life Sciences) and goat anti-mouse IgG (cat. no. BL001A; 1:5,000; Biosharp Life Sciences). 
Culture of PECs. PECs were isolated and cultured using previously established methods $(10,16)$. Fresh primary pterygium samples at the advanced stage were washed with PBS with $1 \%$ penicillin (100 units/ml) and streptomycin (100 $\mu \mathrm{g} / \mathrm{ml})(\mathrm{Gibco}$; Thermo Fisher Scientific, Inc.). After the fibrovascular tissue was removed as much as possible, the remaining epithelial tissues were cut into small pieces of $1 \times 1 \mathrm{~mm}$ and then cultured in DMEM supplemented with 10\% FBS (Gibco; Thermo Fisher Scientific, Inc.), $100 \mathrm{U} / \mathrm{ml}$ penicillin and $100 \mathrm{mg} / \mathrm{ml}$ streptomycin at $37^{\circ} \mathrm{C}$ with $5 \% \mathrm{CO}_{2}$ in a humidified incubator. The solution was changed once every 2-3 days, and after the cells covered the bottom of the bottle, the cells were digested with $0.25 \%$ trypsin (Gibco; Thermo Fisher Scientific, Inc.) at $37^{\circ} \mathrm{C}$ for $2 \mathrm{~min}$. Under a phase-contrast microscope, once cytoplasmic retraction and enhanced refractive index had been observed, $2 \mathrm{ml}$ medium with $10 \%$ FBS was added to terminate digestion. The cell suspension was prepared, counted and inoculated. Finally, PECs were seeded in serum-free DMEM and cultured at $37^{\circ} \mathrm{C}, 5 \%$ $\mathrm{CO}_{2}$, in a saturated humidity incubator. The cells from primary culture using tissue were defined as primary passage cells (P0) and the cells from the first passage after the primary culture were defined as first passage PECs (P1). The morphology of cells was relatively uniform, showing a fibrous/fusiform shape. Immunofluorescence results confirmed that almost all cells (P2) were positively stained with anti-cytokeratin 13 (cat. no. ab32522; 1:200; Abcam) at $4^{\circ} \mathrm{C}$ overnight, so the cell purity was considered to be very high, close to $100 \%$ (Fig. 1).

UVB irradiation of PECs. The cultured PECs were incubated in a 96-well culture plate with $4 \times 10^{3}$ cells/well for $24 \mathrm{~h}$. Culture medium was removed and replaced with PBS. The PECs were irradiated with UVB at a dose of $0,0.5,1$ and $2.0 \mathrm{~J} / \mathrm{cm}^{2}$ using an UV irradiation chamber BS-02 (Opsytec Dr. Gröbel GmbH). PECs were collected for analysis of Livin expression, and analysis of cell viability and invasion ability following UVB irradiation.

CCK-8 assay for cell viability. Following UVB irradiation, PECs were incubated in 96-well plates at $100 \mu \mathrm{l} /$ well with 5 replicate wells for each group for $24 \mathrm{~h}$. Subsequently, $10 \mu \mathrm{l}$ CCK8 was added to each well for analysis of cell viability according to the manufacturer's protocol (Shanghai Yeasen Biotech Co., Ltd.). Blank control wells were set and incubated at $37^{\circ} \mathrm{C}$ in the dark. The optical density (OD) value was read at a wavelength of $450 \mathrm{~nm}$ using a microplate reader Plus384 (Molecular Devices LLC) and the cell survival rate was calculated using the following formula: Cell viability $(\%)=\left(\right.$ experimental group $\mathrm{OD}_{450} /$ normal group $\left.\mathrm{OD}_{450}\right) \times 100$. The experiment was repeated three times.

PEC transfection. Small interfering RNA (siRNA) was used to knockdown endogenous Livin gene expression in PECs. Cells were transfected with Livin-specific siRNA (GE Healthcare Dharmacon, Inc.) and negative control scrambled siRNA using Lipofectamine ${ }^{\circledR} 2000$ (Thermo Fisher Scientific, Inc.) according to the manufacturer's protocol. The PECs were seeded at a density of $1 \times 10^{5}$ cells/well in 6-well plates and transfected with $30 \mathrm{nM}$ Livin-siRNA using Lipofectamine 2000. After $48 \mathrm{~h}$ of incubation at $37^{\circ} \mathrm{C}$, the cells were harvested and subjected to cell viability, migration and invasion assays, and flow cytometry analysis.
A

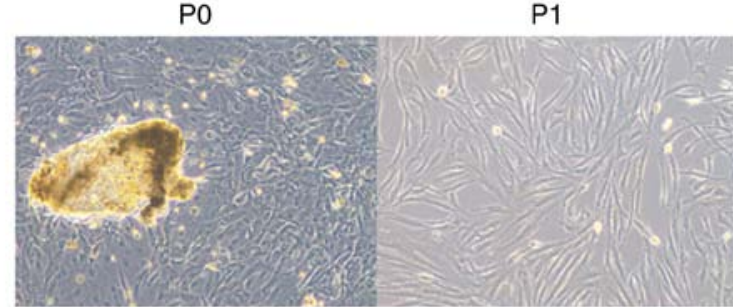

B

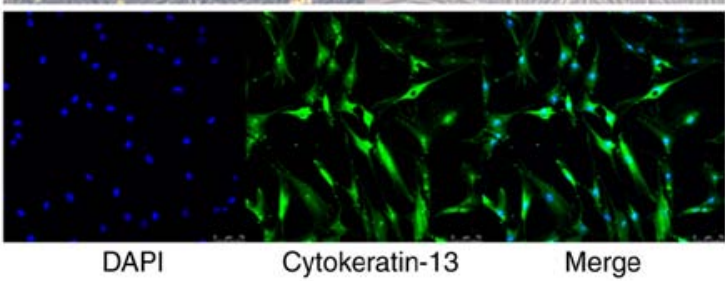

Figure 1. Culture and identification of PECs. (A) Cell morphology of the primary passage ( $\mathrm{P} 0)$ and first passaged ( $\mathrm{P} 1) \mathrm{PECs}$ under light microscope. Magnification, x100. (B) Immunofluorescent staining using fluorescence microscopy showing blue nuclear staining (DAPI) and green cytokeratin 13 staining. Magnification, x200. PECs, pterygium epithelial cells; P, passage.

Cell apoptosis assay. Apoptosis was determined using an Annexin V-FITC/7-AAD assay. After transfection with Livin-siRNA, PECs were incubated at $37^{\circ} \mathrm{C}$ for $48 \mathrm{~h}$. A total of $5 \times 10^{4}$ cells were collected by centrifugation at $500 \mathrm{xg}$ for $5 \mathrm{~min}$ at room temperature, washed twice with PBS and centrifuged again at $500 \mathrm{x} \mathrm{g}$ for $10 \mathrm{~min}$ at $37^{\circ} \mathrm{C}$. A total of $100 \mu \mathrm{l}$ binding buffer was used to re-suspend the cells. After adding $5 \mu \mathrm{l}$ Annexin V-FITC and $5 \mu \mathrm{l}$ 7-AAD (both Beijing Jiamay Biotech), the cells were incubated for $15 \mathrm{~min}$ at room temperature in the dark. After adding $400 \mu \mathrm{l}$ binding buffer, cell apoptosis was detected using a NovoCyte flow cytometer (ACEA Biosciences, Inc.). The cells that were FITC-positive and 7-AAD-negative were indicated as apoptotic cells.

Cell migration assay. A total of $1 \times 10^{5}$ cultured PECs/well were seeded in a 6-well culture plate. After incubation for $24 \mathrm{~h}$ at $37^{\circ} \mathrm{C}$, a straight line was scratched across the cells using a P200 pipette tip to create a wound. The plates were then rinsed with PBS to remove the cells in suspension. Identical sites were observed at $\times 40$ magnification at 0 and $24 \mathrm{~h}$ post-scratching using a light microscope. The migration of cells toward the wounds was expressed as percentage of wound closure: $\%$ of wound closure $=[(\mathrm{At}=0 \mathrm{~h}-\mathrm{At}=\Delta \mathrm{h}) / \mathrm{At}=0 \mathrm{~h}]$ $\mathrm{x} 100 \%$. At $=0 \mathrm{~h}$ is the area of wound measured immediately after scratching; $A t=\Delta \mathrm{h}$ is the area of wound measured $24 \mathrm{~h}$ after scratching.

Cell invasion assay. Cell invasion was measured in a Transwell cell culture chamber. Cultured PECs were seeded in the upper chambers with $25 \mu \mathrm{g}$ Matrigel $(8-12 \mathrm{mg} / \mathrm{ml})$. A total of $100 \mu \mathrm{l}$ cell suspension using serum-free medium was added to the upper chamber $\left(9 \times 10^{3}\right.$ cells/chamber) and $600 \mu 1$ DMEM containing $10 \%$ serum as a chemokine was added to the lower chamber. Incubation was performed at $37^{\circ} \mathrm{C}$ with $5 \%$ $\mathrm{CO}_{2}$ for $48 \mathrm{~h}$. The chamber was then removed, washed three times with PBS, fixed with immobilization solution for $20 \mathrm{~min}$ and washed three times with PBS. After staining with crystal violet for $20 \mathrm{~min}$ at room temperature, the cells were counted 
Table I. Livin expression in pterygium and normal conjunctiva tissues.

\begin{tabular}{lcrr}
\hline Livin expression level & Normal conjunctiva, $\mathrm{n}(\%)$ & Quiescent pterygium, n (\%) & Advanced pterygium, $(\%)$ \\
\hline 0 & $9(90.0)$ & $4(23.5)$ & $3(16.7)$ \\
+ & $1(10.0)$ & $5(29.4)$ & $3(16.7)$ \\
++ & $0(0.0)$ & $6(35.3)$ & $7(38.9)$ \\
+++ & $0(0.0)$ & $2(11.8)$ & $5(27.8)$ \\
Total positive & $1(10)$ & $13(76.5)$ & $15(83.3)$ \\
\hline
\end{tabular}

0 , no positive staining;,$+ 1-10 \% ;++, 11-50 \%$; and,$+++>50 \%$ positive cells. Scores of,+++ and +++ represent positive immunostaining, and a score of 0 represents negative immunostaining.

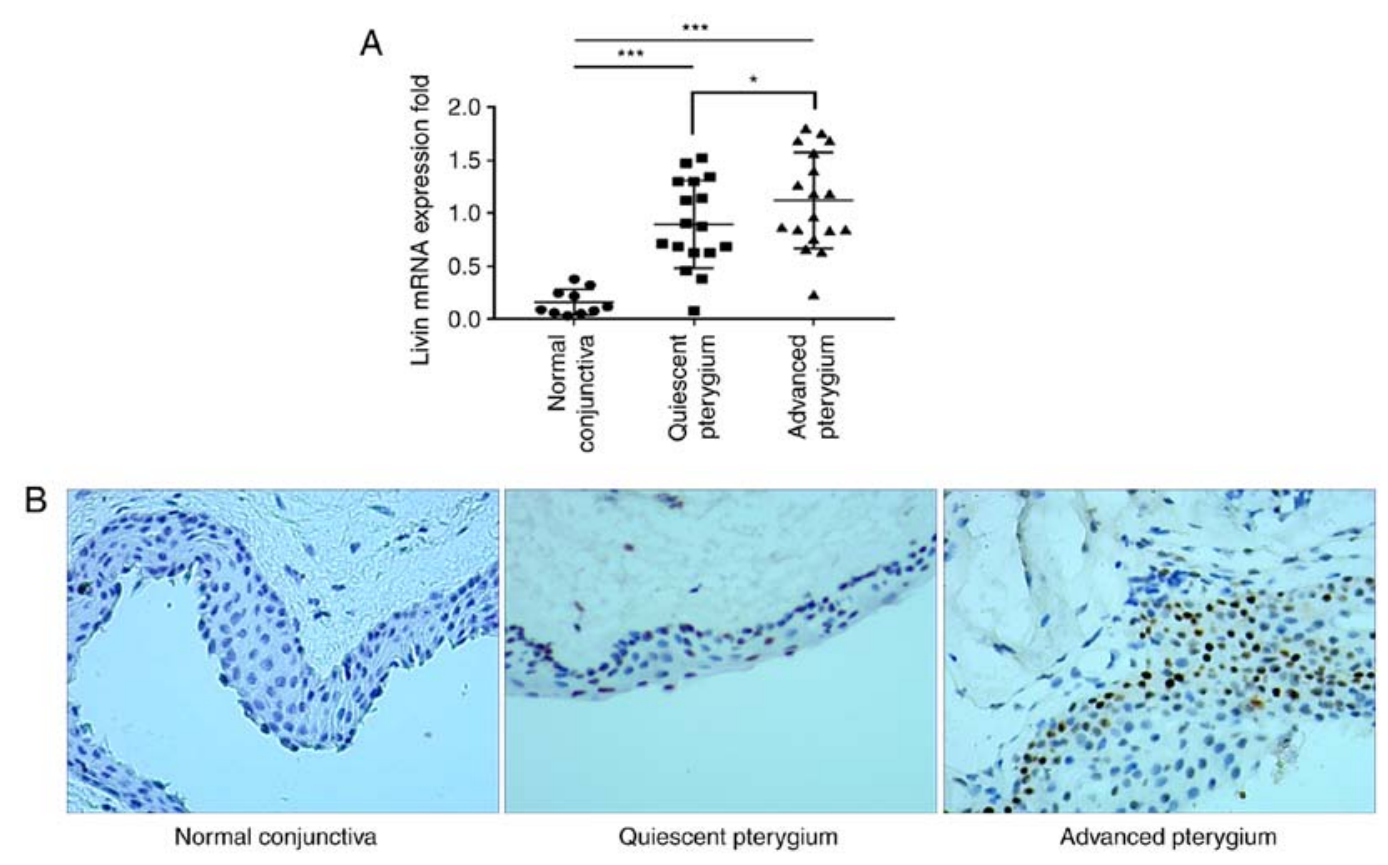

Figure 2. Livin expression in normal conjunctiva $(n=10)$, quiescent pterygium $(n=17)$ and advanced pterygium ( $n=18)$ tissues. (A) Reverse transcription-quantitative PCR detection of Livin mRNA expression levels. ${ }^{*} \mathrm{P}<0.05$ and ${ }^{* * * *} \mathrm{P}<0.001$. (B) Immunohistochemistry detection of Livin protein. Representative immunostaining results are presented. Magnification, x200. Normal conjunctiva was negative for expression of Livin. Quiescent pterygium exhibited positive expression of Livin scored as + and ++. Advanced pterygium showed positive expression of Livin scored as ++ and +++.

under a light microscope (magnification, x200). Results of three individual experiments were averaged.

Statistical analysis. The data are expressed as the mean \pm standard deviation of at least three independent experiments. All datasets were tested for normality with the Kolmogorov-Smirnov test. When data were normally distributed, one-way ANOVA with Tukey's post hoc test was performed for multiple comparisons, and Student's t-test was used for comparison between two groups. A $\chi^{2}$ test was used for compare Livin staining scores. $\mathrm{P}<0.05$ was considered to indicate a statistically significant difference.

\section{Results}

Livin expression levels are upregulated in pterygium compared with those in normal conjunctiva. The Livin expression levels were analyzed in normal human conjunctiva and pterygium tissues using RT-qPCR. Livin mRNA expression levels were increased 5-fold in quiescent stage pterygium and 5.3-fold in the pterygium at the advanced stage compared with that in the normal conjunctiva (Fig. 2A). Advanced stage pterygium tissues exhibited significantly higher Livin mRNA expression levels compared with quiescent stage tissues (Fig. 2A). Immunohistochemistry demonstrated that Livin protein was expressed in pterygium tissues primarily located in the nuclei of epithelial cells, whereas it was seldom expressed in the normal conjunctiva (Fig. 2B).

In the pterygium group, $28 / 35$ samples $(80.0 \%)$ stained positively for Livin, whereas in the normal conjunctiva group only $1 / 10$ samples $(10.0 \%)$ demonstrated Livin-positive staining. The difference between the pterygium and normal conjunctiva groups was significant ( 80.0 vs. $10 \%$; $\mathrm{P}<0.001)$. Staining scores were higher in advanced-stage compared with quiescent-stage samples (Table I).

Knockdown of Livin expression impairs cell migration, invasion and viability, and induces apoptosis in PECs. To 


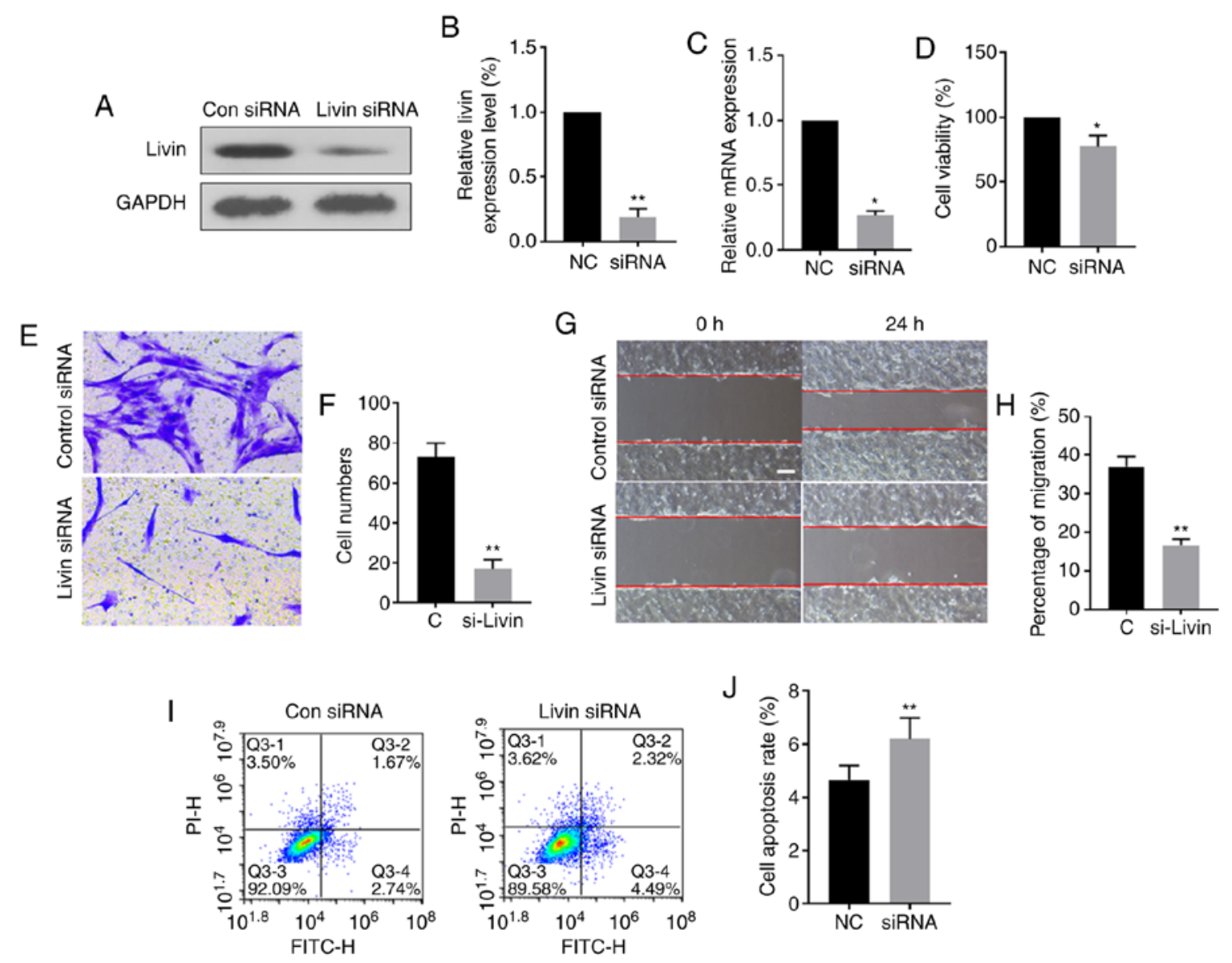

Figure 3. Knockdown of Livin by siRNA and the effect on PECs. (A and B) Western blotting showed that Livin protein was significantly downregulated in Livin-siRNA-transfected PECs. (C) Relative Livin mRNA expression levels were significantly reduced in Livin-siRNA-treated PECs. (D) Cell viability of PECs decreased after Livin-knockdown in CCK-8 assay. (E and F) Cell invasion ability was reduced after knock-out of Livin in PECs. Magnification, x200. $(\mathrm{G}$ and $\mathrm{H})$ Cell migration ability was reduced in Livin-siRNA-transfected PECs. Scale bar, $50 \mu \mathrm{m}$. (I and J) Cell apoptosis increased after transfection with Livin-siRNA in PECs. "P<0.05 and ${ }^{* *} \mathrm{P}<0.01$. siRNA, small interfering RNA; PECs, pterygium epithelial cells; Con, control; C, control; NC, negative control.

further evaluate the role of Livin in pterygium development and progression, ex vivo cultured PECs were transfected with Livin-siRNA or control siRNA. Western blot analysis showed that the expression levels of Livin protein and mRNA were significantly downregulated in the Livin-siRNA-transfected group compared with those in the control group, suggesting successful knockdown of Livin in Livin-siRNA-transfected PECs (Fig. 3A-C). Knockdown of Livin expression significantly reduced invasion, migration and viability of PECs (Fig. 3D-H) and the proportion of apoptotic cells was increased in Livin-siRNA-transfected PECs compared with that in negative control siRNA-transfected PECs (Fig. 3I and J).

Livin regulates EMT and apoptosis via E-cadherin, Snail, caspases and PARP. Previous studies have demonstrated that EMT is an initial step required for cell metastasis and that it has a role in apoptotic resistance (19). Therefore, the role of Livin in regulating the expression of EMT-associated proteins was also investigated. The data indicate that knockdown of Livin expression significantly increased E-cadherin and reduced Snail expression levels (Fig. 4A and B), indicating Livin is involved in the regulation of EMT. The protein expression levels of apoptosis-associated enzymes, caspase-3 and 7 , were significantly increased in the Livin-knockdown
PECs. PARP protein expression levels were also increased in Livin-knockdown PECs, but this difference was not significant (Fig. 4B).

Effect of UVB irradiation on Livin expression, cell viability and invasion ability in PECs. UVB is a major risk factor for pterygium development (3). To further investigate the association between Livin expression levels and cell viability and invasion following UVB irradiation, ex vivo PECs in culture were treated with UVB radiation. Compared with the non-radiation treatment group, Livin protein expression levels were significantly increased in UVB irradiation-treated PECs (Fig. 5A) and PEC viability was significantly increased with increasing doses of UVB radiation (Fig. 5B). In addition, cell invasion was promoted by UVB irradiation (Fig. 5C).

UVB irradiation may promote the development and progression of pterygium by inducing the expression of Livin. Western blot analysis was used to evaluate Livin protein expression following UVB irradiation with or without Livin-knockdown. Livin-knockdown followed by UVB irradiation resulted in partial inhibition of UVB-induced Livin protein expression (Fig. 6A and B). In the invasion experiments, UVB induced an increase in cell invasion ability, which was attenuated by Livin silencing (Fig. 6C and D). Cell apoptosis analysis revealed that UVB 
A

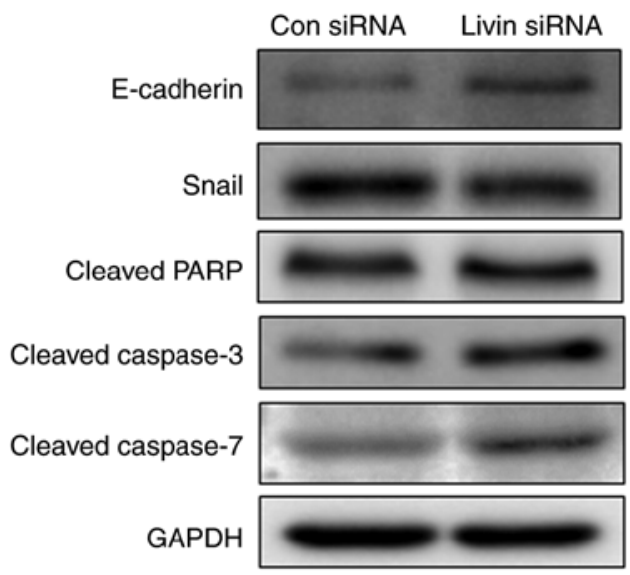

B

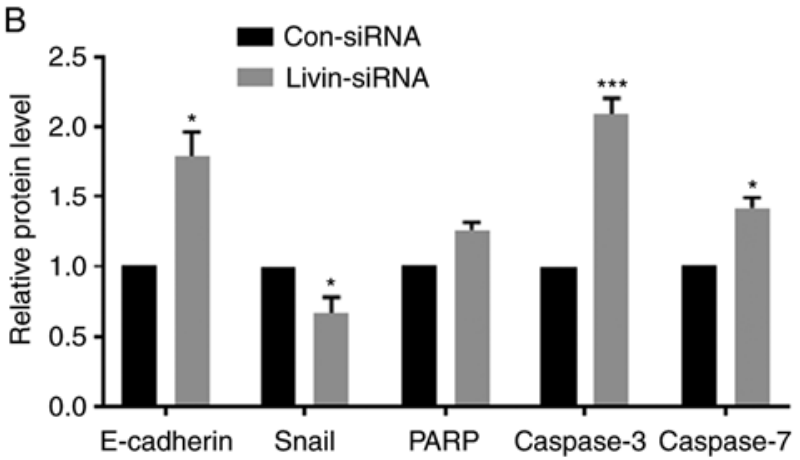

Figure 4. Effects of Livin silencing on the mediators of the epithelial-mesenchymal transition and apoptosis in PECs. (A) Western blotting showed that expression levels of E-cadherin, cleaved caspase-3, cleaved caspase-7 and PARP were upregulated in PECs, whereas Snail was downregulated. (B) Mean relative Livin level in PECs transfected with control siRNA or Livin-siRNA. ${ }^{*} \mathrm{P}<0.05$ and ${ }^{* * *} \mathrm{P}<0.001$. PECs, pterygium epithelial cells; PARP, poly ADP-ribose polymerase; Con, control; siRNA, small interfering RNA.

irradiation reduced apoptosis of PECs, and transfection with Livin-siRNA prior to UVB irradiation increased the apoptosis of PECs compared with the control siRNA group (Fig. 6E and F).

\section{Discussion}

Pterygium is a fibrovascular neoformation composed of epithelium and highly vascular loose subepithelial connective tissue (20). Previous studies have demonstrated that apoptotic and oncogenic proteins, microsatellite instability, inflammatory mediators, extracellular matrix modulators, EMT and other factors are involved in the development of pterygium $(4,9-11,13)$. However, to the best of our knowledge, the precise molecular mechanisms of pterygium pathogenesis have not been resolved. It is hypothesized that epithelial cells function in the pathogenesis of pterygium, with EMT and secretion of matrix metalloproteinases from epithelial cells associated with the invasive and recurrent behavior of pterygium (21-23).

Previous studies have demonstrated that a number of apoptosis-associated genes and proteins are differentially expressed in pterygium compared with normal conjunctiva tissues, including p53, Survivin and Bcl-2, indicating the role of apoptosis in the pathogenesis of pterygium $(12,16,24)$. Pterygium may be associated with disrupted control of cellular apoptosis
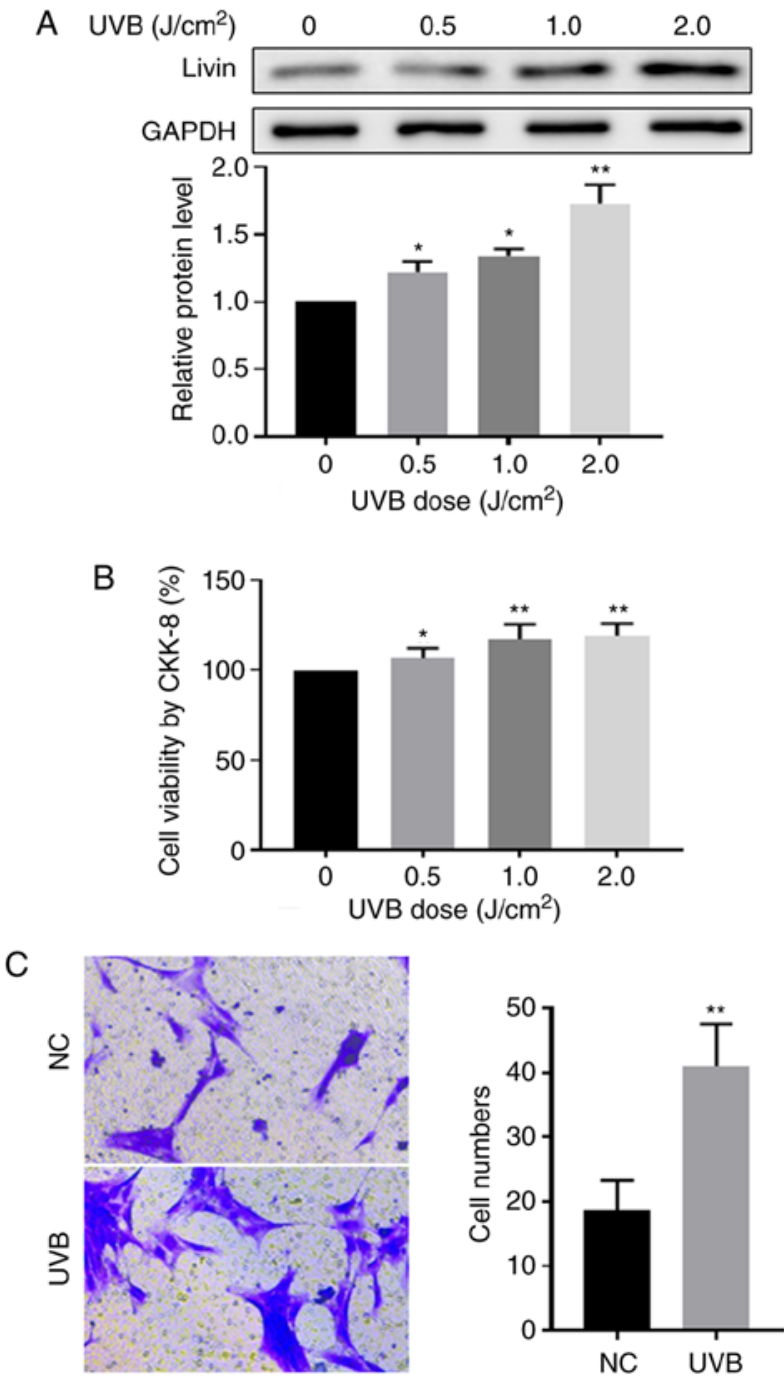

Figure 5. Effect of UVB irradiation on Livin expression levels and cell viability and invasion ability of pterygium epithelial cells. (A) With the increase of low-dose UVB irradiation, Livin protein expression levels increased. (B) Cell viability was significantly enhanced after UVB irradiation. (C) Cell invasion ability was enhanced after UVB irradiation. " $\mathrm{P}<0.05$ and ${ }^{* *} \mathrm{P}<0.01$. UVB, ultraviolet $\mathrm{B}$ radiation; $\mathrm{NC}$, negative control.

rather than an increase in proliferative capacity, therefore, the regulation of PEC apoptosis may have a role in the pathogenesis of pterygium (25). As a member of the IAP family, Livin participates in apoptosis, proliferation and the cell cycle by binding to caspases and regulation of EMT $(14,26)$. Livin is not expressed in the majority of normal adult tissues; however, it is present in developmental tissues and highly expressed in most tumor tissues (27). In the present study, the molecular mechanism underlying the function of Livin in the pathogenesis of pterygium was investigated. Livin mRNA and protein expression levels were significantly upregulated in pterygium tissues compared with those in the normal conjunctiva. Moreover, Livin expression levels were higher in advanced pterygium compared with those in quiescent pterygium tissues. This difference may be due to the higher cell proliferation pattern in advanced pterygium compared with that in quiescent pterygium. Therefore, upregulated Livin may be involved in the occurrence and development of pterygium, which requires further research. In the present study, cultured PECs were 

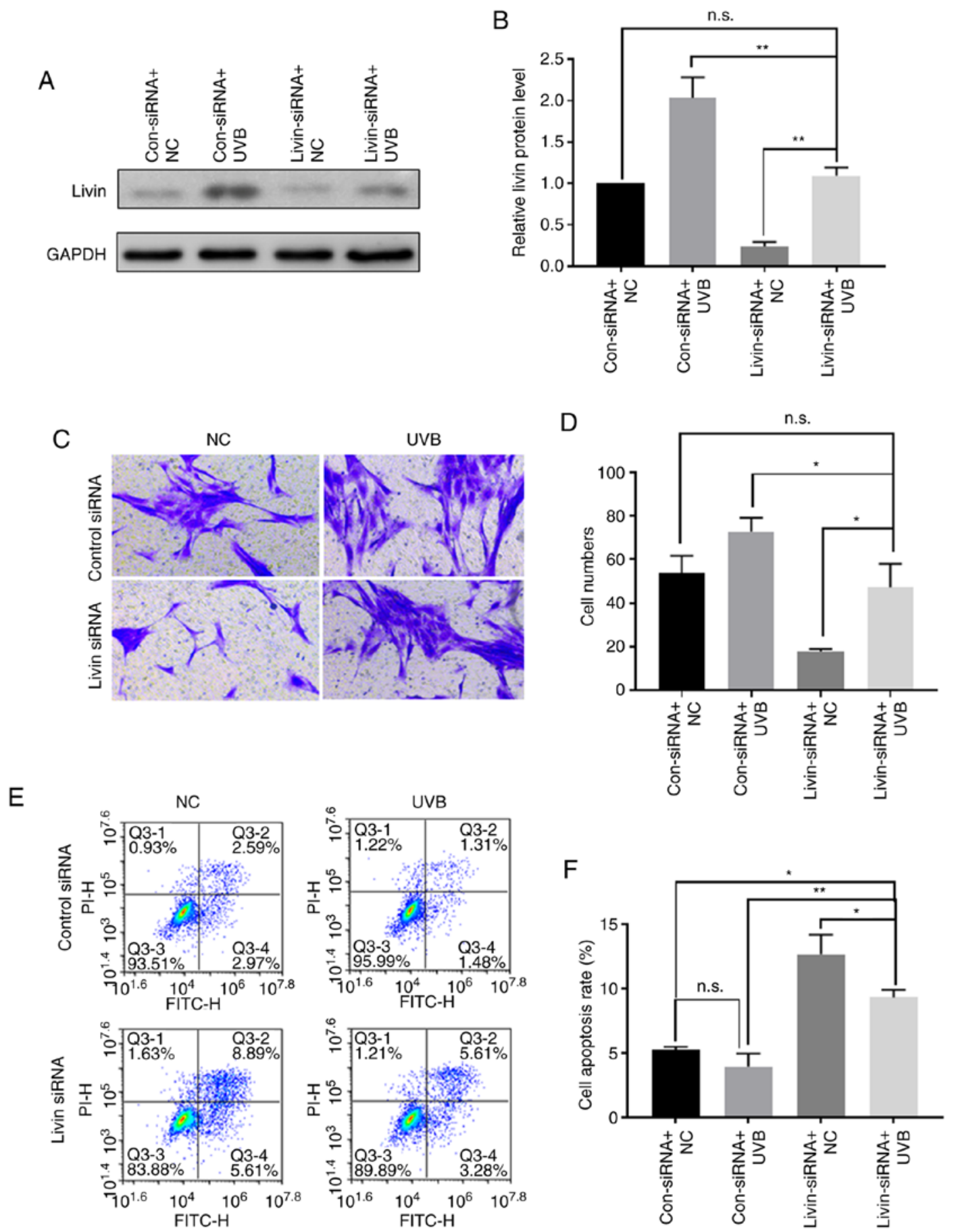

Figure 6. Effects of UVB irradiation and Livin-siRNA on cell invasion ability and cell apoptosis in PECs. PECs were pretreated with Livin-siRNA or control-siRNA, then cells were irradiated with UVB or not irradiated. (A and B) Livin protein expression levels were partially inhibited by Livin-siRNA transfection prior to UVB irradiation. (C and D) Increase in cell invasion ability induced by UVB was attenuated by preconditioning knockdown of Livin expression. (E and F) UVB irradiation reduced apoptosis of PECs, whereas transfection of Livin-siRNA prior to UVB irradiation increased apoptosis of PECs. ${ }^{*} \mathrm{P}<0.05$ and ${ }^{* *} \mathrm{P}<0.01$. n.s., not significant; UVB, ultraviolet B radiation; PECs, pterygium epithelial cells; siRNA, small interfering RNA; Con, control.

also used for further investigation of the association between Livin and the development of pterygium. Livin expression in advanced pterygium may have a role in promoting epithelial proliferation, resulting in progression of the pterygium.

To explore whether Livin expression is involved in the occurrence and development of pterygium, PECs were transfected with Livin-siRNA in the present study. Knockdown of Livin expression levels increased apoptosis of PECs and decreased their proliferation, migration and invasion abilities, which is consistent with the results of a previous study investigating other IAPs (16). It is hypothesized that EMT occurs during the pathogenesis of pterygium (13). Snail is a key transcription factor involved in EMT regulation (28). E-cadherin is downregulated in during EMT, associated with the detachment and invasion of cells from their primary site, and results in metastasis and progression $(13,28,29)$. In the present study, Livin-knockdown reduced Snail expression and increased E-cadherin expression, consistent with the reduced 
proliferation, migration and invasion of PECs following Livin-knockdown, indicating that Livin may be associated with EMT. Therefore, Livin may be involved in the pathogenesis of pterygium via a function in EMT.

IAPs suppress apoptosis induced by a range of stimuli, primarily via direct binding of the BIR domain to specific intracellular proteases, including caspase-3, -7 and -9, inhibiting their activity (24). PARP is an important downstream substrate of caspase-3 (30). In the present study, Livin-knockdown increased the expression of caspase-3, -7 and PARP, consistent with results of a previous study investigating the function of Livin in oral squamous cells $(27,31)$. Therefore, the anti-apoptotic function of Livin may be mediated by suppressing the activity of caspases in PECs.

A number of studies have demonstrated that UV exposure is a factor precipitating the development of pterygium $(3,21,32,33)$. Histological examination has confirmed that elastic connective tissue lesions and severely damaged areas of the Bowman membrane indicate direct damage caused by solar radiation or indirect damage due to excessive proteolytic activity $(3,21)$. The present study showed that Livin expression levels were increased by UVB irradiation and contributed to the increased cell viability and invasion ability in PECs. Meanwhile, knockdown of Livin expression attenuated the effects of UVB-induced Livin expression level on cell viability and cell invasion in PECs. This decreased cell viability and invasion ability in Livin-knockdown PECs following UVB exposure suggests that Livin may have a role in inducing pterygium formation by increasing cell viability and invasion. PEC apoptosis was reduced by low-dose UVB irradiation, and knockdown of Livin prior to UVB irradiation increased the apoptosis of PECs. Therefore, the increase in cell viability and invasion induced by UVB irradiation may be due to upregulated Livin expression, and silencing of Livin expression may protect against pterygium development.

Overall, the present study suggests that increased Livin expression levels may be involved in the pathogenesis and development of pterygium. Knockdown of Livin reduced the proliferation, migration and invasion of PECs, and induced apoptosis by regulating EMT and apoptosis-associated proteins. UVB radiation increased the expression of Livin and cell invasion; therefore, UVB is a risk factor for pterygium. The present study provides novel insight into the pathogenesis of pterygium and may contribute to the development of novel therapeutic agents for treatment. However, the interaction between Livin and other cytokines and growth factors in pterygium development still requires further investigation.

\section{Acknowledgements}

Not applicable.

\section{Funding}

This study was supported by The Natural Science Foundation of Zhejiang Province (grant no. LY17H120009) and The Zhejiang Traditional Chinese Medicine Science and Technology Project (grant no. 2016ZA151).

\section{Availability of data and materials}

The datasets during the current study are available from the corresponding author on reasonable request.

\section{Authors' contributions}

SQW, QBX, WYS and LWZ designed the study. SQW, QBX and LWZ drafted the original manuscript, collected the data and reviewed the literature. QBX, WYS and LYS interpreted the data and critically reviewed the manuscript. All authors have read and approved the final manuscript.

\section{Ethics approval and consent to participate}

The present study was approved by The Institutional Review Board at Hangzhou Red-Cross Hospital (Hangzhou, China) and written informed consent was provided by all patients.

\section{Patient consent for publication}

Not applicable.

\section{Competing interests}

The authors declare that they have no competing interests.

\section{References}

1. Liu T, Liu Y, Xie L, He X and Bai J: Progress in the pathogenesis of pterygium. Curr Eye Res 38: 1191-1197, 2013.

2. Nuzzi R and Tridico F: How to minimize pterygium recurrence rates: Clinical perspectives. Clin Ophthalmol 12: 2347-2362, 2018.

3. Zhou WP, Zhu YF, Zhang B, Qiu WY and Yao YF: The role of ultraviolet radiation in the pathogenesis of pterygia (Review). Mol Med Rep 14: 3-15, 2016.

4. Cardenas-Cantu E, Zavala J, Valenzuela J and Valdez-Garcia JE: Molecular basis of pterygium development. Semin Ophthalmol 31: 567-583, 2016.

5. Di Girolamo N, Chui J, Coroneo MT and Wakefield D: Pathogenesis of pterygia: Role of cytokines, growth factors, and matrix metalloproteinases. Prog Retin Eye Res 23: 195-228, 2004.

6. Maurizi E, Schiroli D, Atkinson SD, Mairs L, Courtney DG, O'Hagan B, McGilligan VE, Pagnamenta AT, Taylor JC, Vasquez JJD, et al: A novel role for CRIM1 in the corneal response to UV and pterygium development. Exp Eye Res 179: 75-92, 2019.

7. Segev F, Mimouni M, Tessler G, Hilely A, Ofir S, Kidron D and Bahar I: A 10-year survey: Prevalence of ocular surface squamous neoplasia in clinically benign pterygium specimens. Curr Eye Res 40: 1284-1287, 2015.

8. Oellers P, Karp CL, Sheth A, Kao AA, Abdelaziz A, Matthews JL, Dubovy SR and Galor A: Prevalence, treatment, and outcomes of coexistent ocular surface squamous neoplasia and pterygium. Ophthalmology 120: 445-450, 2013.

9. Qin YJ, Chu WK, Huang L, Ng CHY, Chan TCY, Cao D, Yang C, Zhang L, Huang SP, Li J, et al: Induction of apoptosis in pterygium cells by antagonists of growth hormone-releasing hormone receptors. Invest Ophthalmol Vis Sci 59: 5060-5066, 2018.

10. Cui YH, Li HY, Gao ZX, Liang N, Ma SS, Meng FJ, Li ZJ and Pan HW: Regulation of apoptosis by miR-122 in pterygium via targeting Bcl-w. Invest Ophthalmol Vis Sci 57: 3723-3730, 2016.

11. Liang K, Jiang Z, Ding BQ, Cheng P, Huang DK and Tao LM: Expression of cell proliferation and apoptosis biomarkers in pterygia and normal conjunctiva. Mol Vis 17: 1687-1693, 2011.

12. Tan DT, Tang WY, Liu YP, Goh HS and Smith DR: Apoptosis and apoptosis related gene expression in normal conjunctiva and pterygium. Br J Ophthalmol 84: 212-216, 2000. 
13. Meshkani SE, Kooshan N, Moghadam AB, Falanji F, Adli A, Baghbani-Arani F, Arian AG and Rad A: Signaling roadmap to epithelial-mesenchymal transition in pterygium, TWIST1 centralized. J Cell Physiol 234: 18146-18155, 2019.

14. Kasof GM and Gomes BC: Livin, a novel inhibitor of apoptosis protein family member. J Biol Chem 276: 3238-3246, 2001.

15. Wang Z, Liu S, Ding K, Ding S, Li C, Gao D, Zhang T and Bi D: Silencing Livin induces apoptotic and autophagic cell death, increasing chemotherapeutic sensitivity to cisplatin of renal carcinoma cells. Tumour Biol 37: 15133-15143, 2016.

16. Xu YX, Zhang LY, Zou DL, Liu ZS, Shang XM, Wu HP, Zhou Y, $\mathrm{He} \mathrm{H}$ and Liu ZG: Differential expression and function of survivin during the progress of pterygium. Invest Ophthalmol Vis Sci 55: 8480-8487, 2014.

17. Livak KJ and Schmittgen TD: Analysis of relative gene expression data using real-time quantitative PCR and the 2(-Delta Delta C(T)) method. Methods 25: 402-408, 2001.

18. Di Girolamo N, McCluskey P, Lloyd A, Coroneo MT and Wakefield D: Expression of MMPs and TIMPs in human pterygia and cultured pterygium epithelial cells. Invest Ophthalmol Vis Sci 41: 671-679, 2000.

19. Pearlman RL, Montes de Oca MK, Pal HC and Afaq F: Potential therapeutic targets of epithelial-mesenchymal transition in melanoma. Cancer Lett 391: 125-140, 2017.

20. Safi H, Kheirkhah A, Mahbod M, Molaei S, Hashemi H and Jabbarvand M: Correlations between histopathologic changes and clinical features in pterygia. J Ophthalmic Vis Res 11: $153-158,2016$

21. Di Girolamo N, Wakefield D and Coroneo MT: UVB-mediated induction of cytokines and growth factors in pterygium epithelial cells involves cell surface receptors and intracellular signaling. Invest Ophthalmol Vis Sci 47: 2430-2437, 2006.

22. Peng J, Sha XY, Liu Y, Yang RM and Wen Y: Pterygium epithelium abnormal differentiation related to activation of extracellular signal-regulated kinase signaling pathway in vitro. Int J Ophthalmol 8: 1118-1125, 2015

23. Tsai YY, Chiang CC, Yeh KT, Lee H and Cheng YW: Effect of TIMP-1 and MMP in pterygium invasion. Invest Ophthalmol Vis Sci 51: 3462-3467, 2010.
24. Weinstein O, Rosenthal G, Zirkin H, Monos T, Lifshitz T and Argov S: Overexpression of p53 tumor suppressor gene in pterygia. Eye (Lond) 16: 619-621, 2002.

25. Maxia C, Perra MT, Demurtas P, Minerba L, Murtas D, Piras F, Corbu A, Gotuzzo DC, Cabrera RG, Ribatti D and Sirigu P: Expression of survivin protein in pterygium and relationship with oxidative DNA damage. J Cell Mol Med 12: 2372-2380, 2008.

26. Han Y, Zhang L, Wang W, Li J and Song M: Livin promotes the progression and metastasis of breast cancer through the regulation of epithelialmesenchymal transition via the p38/GSK3beta pathway. Oncol Rep 38: 3574-3582, 2017.

27. Yan B: Research progress on Livin protein: An inhibitor of apoptosis. Mol Cell Biochem 357: 39-45, 2011.

28. Huber MA, Kraut N and Beug H: Molecular requirements for epithelial-mesenchymal transition during tumor progression. Curr Opin Cell Biol 17: 548-558, 2005.

29. Kato N, Shimmura S, Kawakita T, Miyashita H, Ogawa Y, Yoshida S, Higa K, Okano H and Tsubota K: Beta-catenin activation and epithelial-mesenchymal transition in the pathogenesis of pterygium. Invest Ophthalmol Vis Sci 48: 1511-1517, 2007.

30. Slee EA, Adrain C and Martin SJ: Executioner caspase-3, -6, and -7 perform distinct, non-redundant roles during the demolition phase of apoptosis. J Biol Chem 276: 7320-7326, 2001.

31. Lee HS, Lee JH and Yang JW: Effect of porcine chondrocyte-derived extracellular matrix on the pterygium in mouse model. Graefes Arch Clin Exp Ophthalmol 252: 609-618, 2014.

32. Aletras AJ, Trilivas I, Christopoulou ME, Drakouli S Georgakopoulos CD and Pharmakakis N: UVB-mediated down-regulation of proteasome in cultured human primary pterygium fibroblasts. BMC Ophthalmol 18: 328, 2018.

33. Di Girolamo N, Kumar RK, Coroneo MT and Wakefield D: UVB-mediated induction of interleukin- 6 and -8 in pterygia and cultured human pterygium epithelial cells. Invest Ophthalmol Vis Sci 43: 3430-3437, 2002.

This work is licensed under a Creative Commons Attribution-NonCommercial-NoDerivatives 4.0 International (CC BY-NC-ND 4.0) License. 